\title{
References
}

1. The Bruges Communiquéon enhanced European Cooperationin Vocational Education and Trainingfor the period 2011-2020 (7 December 2010).

2. Vasianovych H. P. Informatsiini tekhnolohii dlia yakisnoi ta dostupnoi osvity / H. P. Vasianovych // Pedahohichna i psykholohichna nauky v Ukraini. Zbirnyk naukovykh prats do 15richchia APN Ukrainy u 5 tomakh. - T. 5: Neperervna profesiina osvita: teoriia i praktyka. - K. : Pedahohichna dumka, 2007. - S. 31-240.

3. Praktyka zastosuvannia Zakonu Ukrainy «Pro profesiino-tekhnichnu osvitu»: finansove zabezpechennia navchalnykh zakladiv i ustanov : materialy vyiznoho zasidannia Komitetu Verkhovnoi Rady Ukrainy z pytan nauky i osvity 12 liutoho 2014 roku / redkol. L. M. Hrynevych (holova), V. O. Dzoz, A. M. Dorokhov, O. M. Sych, V. P. Holovinov, Ye. V. Krasniakov, N. H. Nychkalo, V. V. Suprun, B. H. Chyzhevskyi. - K. : Parl. vyd-vo, 2015. - 552 s.

4. Profesiina osvita yak skladova zabezpechennia kvalifikovanoho kadrovoho potentsialu Ukrainy: problemy ta shliakhy vyrishennia : materialy parlam. slukhan u Verkhovnii Radi Ukrainy 1 chervnia 2016 roku // Verkhovna Rada Ukrainy, Komitet z pytan nauky i osvity. - K. : Parlam. vyd-vo, 2016. - 320 s. - (Seriia «Parlamentski slukhannia»).

5. Radkevych V. O. Profesiina osvita i navchannia dlia staloho rozvytku suspilstva /
Valentyna Radkevych // Prof.-tekhn. osvita, 2015. № 4 (69). - S. 7-11.

6. Serheieva L.M. Prakseolohichni zasady rozvytku profesiinoi osvity i navchannia / L. M. Sierhieieva // Problemy ta perspektyvy rozvytku robitnychykh profesii u Chernivetskii oblasti: zastosuvannia novitnikh tekhnolohii u navchanni: Zb. statei oblasnoi nauk.-prakt. konf. - Chernivtsi :ChVKU KNTEU, 2016. - 160 s.

7. Suprun V. V. Modernizatsiia profesiinoi osvity yak upravlinska umova pidhotovky kompetentnykh fakhivtsiv novoi formatsii / V. V. Suprun // Visnyk pisliadyplomnoi osvity : zb. nauk. pr. ; NAPN Ukrainy DVNZ «Un-t menedzh. osvity». - 2017. - Vyp. 3(32). - S. 104-124. - (Seriia «Upravlinnia ta administruvannia»).

8. Finenko O. Yu. Innovatsii v systemi pidhotovky kadriv dlia kharchovoi promyslovosti $\mathrm{v}$ Ukraini / O. Yu. Finenko // Sotsialno-trudovi vidnosyny: teoriia ta praktyka. - 2014. - № 2. S. 392-395. - [Elektronnyi rezhym]. - Rezhym dostupu: http://nbuv.gov.ua/UJRN/stvttp_2014_2_59

9. Sherman Ye. M. Orhanizatsiinoekonomichnyi mekhanizm rozvytku pidpryiemstv kharchovoi promyslovosti: dys. kand. ek. nauk : 08.00.04 / Sherman Yevhen Mykhailovych; M-vo osvity i nauky Ukrainy, Khersonskyi natsionalnyi tekhnichnyi Universytet - Kherson, 2015. - 247 s.

УДК: 377/378.018.43:004]:167.7

\section{ПРОГНОСТИЧНА МОДЕЛЬ ДИСТАНЦІЙНОГО ПРОФЕСІЙНОГО НАВЧАННЯ}

\section{Світлана Кравець,}

кандидат педагогічних наук,

стариий науковий співробітник лабораторії дистанційного професійного навчання Інституту професійно-технічної освіти НАПН України.

ORCID: 0000-0001-6259-0067

\section{КЛЮЧОВІ СЛОВА: \\ дистанційна освіта, дистанційне професійне навчання, прогностична модель дистанційного професійного навчання, заклади професійної (професійно-технічної) освіти.}

\begin{abstract}
Рeферат
На основі аналізу законодавчих актів та нормативно-правових документів 3'ясовано, що актуальність упровадження дистанційної освіти посилюється соціальними, політичними, культурними викликами суспільства, що зумовлює потребу в оновленні нормативноправового супроводу дистанційного навчання, окресленні нових можливостей щодо його впровадження й фінансування.

Схарактеризовано діяльність науковців та практиків щодо поступового впровадження дистанційного навчання у закладах професійної (професійно-технічної) освіти та забезпечення функціонування організаційної структури дистанційної професійної освіти у співвідношенні з явищами, об'єктами, процесами, які є визначальними у системі професійної (професійно-технічної) освіти.

Обгрунтовано прогностичну модель дистанційного професійного навчання, котра містить такі блоки: цільовий - мета, концептуальні підходи та принципи, зовнішні та внутрішні чинники; суб'єктний, що передбачає партнерську взаємодію суб'єктів навчання
\end{abstract}




\begin{abstract}
(педагогів, тьюторів, адміністраторів СДН, учнів/слухачів) в електронному середовищі; змістово-функціональний, що містить компонентну структуру готовності педагогів до впровадження дистанційного навчання кваліфікованих робітників та функції, які має реалізовувати педагог у дистанційному професійному навчанні; організаційно-методичний представлений організаційно-педагогічними умовами та методичним супроводом їх реалізації; результативний блок - механізми оцінювання динаміки рівнів розвитку готовності педагогів до впровадження дистанційного професійного навчання та ефективність застосування дистанційного навчання в закладах професійної (професійно-технічної) освіти.

Узагальнено, що запровадження прогностичної моделі дистанційного професійного навчання в закладах професійної (професійно-технічної) освіти з чіткою орієнтацією на специфіку професійної підготовки майбутніх кваліфікованих робітників відносно обраної професії забезпечить досягнення соціального ефекту, а саме: урізноманітнення форм професійної освіти і навчання; задоволення індивідуальних освітньо-професійних потреб особистості; підвищення якості професійної підготовки учнів/слухачів; зменшення фінансових витрат у системі професійної (професійно-технічної) освіти.
\end{abstract}

Постановка проблеми. Актуальність розвитку дистанційної освіти в Україні нині посилюється соціальними, політичними, культурними викликами суспільства: видозміна характеру праці, інформатизація виробничих процесів, економічна та політична нестабільність, трансформація внутрішніх потреб громадян та ін. Наразі перед системою професійної (професійнотехнічної) освіти постають завдання щодо поєднання традиційних підходів до навчання iз дистанційно організованими формами, моделями освіти, які оптимально задовольняють потреби громадян у підвищенні кваліфікації, підтвердженні досвіду неформальної освіти тощо, вводночас, надаючи можливість особистості не полишати робочого місця, зберігати матеріальну стабільність, дотримуватися вигідної особистісної траєкторії професійного розвитку

Заявлена актуальність розвитку дистанційної форми здобуття освіти та сучасний стан нормативно-правового супроводу й готовності педагогів до впровадження дистанційного професійного навчання окреслюють мету статті розробити й обгрунтувати прогностичну модель дистанційного професійного навчання 3 визначенням організаційно-педагогічних умов оптимального його впровадження в закладах професійної (професійно-технічної) освіти (далі - ЗП(ПТ)О).

\section{Аналіз останніх досліджень.}

Теоретичне та методичне вирішення питань, пов'язаних 3 упровадженням дистанційного навчання взакладах освіти, не $\epsilon$ новим завданням для науковців та практиків. Адже про створення необхідних умов та моделі забезпечення громадян і суспільства своєчасною, достовірною та повною інформацією шляхом широкого використання інформаційних технологій, зокрема й у сфері освіти і науки, було заявлено в Національній програмі інформатизації ще в 1998 році. На виконання завдань цієї програми в 2000 р. було прийнято Концепцію розвитку дистанційної освіти в Україні [1]. На початку XXI ст. про актуальність створення проектів нормативно-правових документів щодо функціонування системи дистанційної освіти та розроблення технологій дистанційного навчання заявлено в Національній доктрині розвитку освіти в Україні у XXI ст. (2002), на виконання завдань якої в 2004 р. було затверджено перше Положення про дистанційне навчання.

3 часом, 3 метою забезпечення організації освітнього процесу за дистанційною формою, у 2013 р. наказом $\mathrm{MOH}$ України затверджено нове Положення про дистанційне навчання зі змінами, внесеними в 2015 р. [5].

Щодо системи професійної (професійно-технічної) освіти, то з'ясовуємо, що в Законі України «Про професійнотехнічну освіту» (1998) однією 3 форм професійно-технічної освіти є дистанційна. Водночас, у проекті Закону України «Про професійну освіту» читаємо, що формами здобуття професійної освіти є «денна, вечірня (змінна), дистанційна».

Прогностично можна передбачити, що сучасні реформи в освітньому законодавстві приведуть до оновлення Положення про дистанційне навчання та інших нормативноправових документів; окреслення нових можливостей щодо впровадження й фінансування дистанційного навчання.

Паралельно $з$ оновленням законодавчих актів та нормативно-правових документів щодо дистанційної форми здобуття освіти у системі професійної (професійно-технічної) освіти поступово здійснюється впровадження 
дистанційного професійного навчання. Спільними зусиллями науковців Інституту професійно-технічної освіти НАПН України і практиків створено Систему дистанційного навчання на базі платформи Moodle (elearning.org.ua); на базі ДНЗ «Дніпропетровський центр професійнотехнічної освіти туристичного сервісу» проводиться дослідно-експериментальна робота за темою «Підготовка кваліфікованих робітників із професій «Квітникар», «Декоратор вітрин», «Флорист» 3 використанням технології дистанційного навчання» (науковий керівник Базелюк О. В.); систематично відбуваються науковопрактичні заходи, орієнтовані на підвищення рівня готовності педагогів до впровадження дистанційного навчання в ЗП(ПТ)О. Безумовно, що функціонування в них організаційної структури дистанційної освіти мають забезпечувати педагоги, беручи активну участь в реалізації організаційноуправлінського, нормативно-правового, навчально-методичного, інформаційнотелекомунікаційного, фінансового компонентів [1].

Більшість педагогів-практиків переконані, що вони $\epsilon$ впевненими користувачами всіх мережевих технологій. Однак результати досліджень, проведених в Інституті професійно-технічної освіти НАПН України співробітниками лабораторії дистанційного професійного навчання в 2017 році щодо стану використання дистанційного професійного навчання у практиці роботи ЗП(ПТ)О засвідчують, що тільки $6,6 \%$ педагогів роблять це систематично й результативно.

Виклад основного матеріалу. Майже кожна наука має свій арсенал методів моделювання, результатом яких є створення різних моделей. У контексті педагогічних процесів та явищ, моделювання передбачає створення специфічного об'єкта - моделі, що відображає інформацію про процеси чи явища, їх властивості та характеристики, внутрішньопроцесуальні взаємозв'язки та зв'язок педагогічної науки 3 практикою. Дослідження взаємозв'язку структури i функцій процесу дистанційного професійного навчання дає змогу змоделювати прогностичну за часовою характеристикою модель (система, що відображає нинішнє та майбутнє буття процесу) [7, с. 138-139], яка за структурою та функціями співвідноситься із явищами, об'єктами, процесами, що $\epsilon$ визначальними у системі професійної (професійно-технічної) освіти.

Надаючи чітке пояснення елементам моделі, ми представляємо прогностичну модель дистанційного професійного навчання як систему 3 основними іiі параметрами i характеристиками, що відображає сукупність взаємопов'язаних між собою елементів i відзначається структурною організацією та функціональним призначенням (рис. 1).

Основним детермінатором розробки й реалізації моделей є мета, в якій закладено прогнозований результат. Досягнення мети базується на дотриманні та продуктивному використанні концептуальних підходів та принципів із врахуванням зовнішніх та внутрішніх чинників впливу на реалізацію мети.

Таким чином, визначальні елементи моделі формують іiі иільовий блок, у якому метою є: забезпечення високого рівня професійної підготовки майбутніх кваліфікованих робітників. Очевидно, що мета прогностичної моделі дистанційного професійного навчання $€$ співзвучною із загальною метою професійної (професійнотехнічної) освіти, адже застосування дистанційного навчання чи окремих технологій відбувається у площині здійснення освітніх процесів у ЗП(ПТ)О, не порушуючи процедурності реалізації стандартів професійної (професійно-технічної) освіти, орієнтуючись на досягнення якісного рівня професійної підготовки майбутніх кваліфікованих робітників на основі упровадження різноманітних педагогічних традиційних та сучасних інформаційних технологій.

Методологічними підходами до організації дистанційного професійного навчання $\epsilon$ реалізація системного, аксіологічного, суб'єктно-діяльнісного, компетентнісного, соціальнореконструкціоністського підходів до професійної підготовки фахівців [3, с. 7-8 ]. Керуючись принципами освітньої діяльності, визначеними ст. 6 Закону України «Про освіту» [6], у цільовому блоці моделі дистанційного професійного навчання виокремлюємо ті, реалізація яких 
уможливлює оптимальність взаємозв'язків між цілями професійної підготовки, специфікою дистанційного навчання та особистісними особливостями суб'єктів навчання. Актуальність використання принципів організації дистанційного професійного навчання посилюється впливом соціально-економічних, політичних та культурних перетворень в суспільстві, які, в свою чергу, видозмінюють позиції суб'єктів навчання щодо пошуку способів задоволення внутрішніх потреб, пов'язаних із потребою реалізацією індивідуальної освітньої траєкторії та професійного розвитку.

Суб'єктний блок моделі передбачає партнерську взаємодію суб'єктів навчання в електронному середовищі. Як зазначає В. Ягупов, педагог $є$ i буде головною постаттю в навчальному процесі, в тому числі й дистанційній формі навчання, бо він організовує цей процес, визначає цілі, завдання, зміст, основні форми, засоби, методи, технології навчальної діяльності учнів, організовує їх на пізнавальнопрактичну діяльність і керує нею, а основним суб'єктом у дистанційній формі набуття професійної освіти $є$ учень та основна форма його навчальної діяльності - цілеспрямована i контрольована самостійна робота [9, с. 32-33]. Процес організації дистанційного навчання зумовлює переосмислення ролі викладача (тьютор, підтримувач процесу, консультант, наставник, дослідник, експерт, менеджер та ін.), що приводить до суттєвої трансформації його особистісних й професійних навичок, якими, на ряду із загальновідомими для педагога, є: інноваційність і креативність, технологічний ентузіазм, відкритість до питань, здатність до рефлексії, якісно новий характер комунікації, відповідальності й автономності [1, с. 81-82].

Змістово-функціональний блок моделі містить структуру готовності педагогів до впровадження дистанційного навчання майбутніх кваліфікованих робітників, компонентами якої є: мотиваційно-ціннісний, когнітивний, операційно-діяльнісний, оціннорефлексивний [1, с. 78]. Рівень сформованості означених компонентів проявляється через реалізацією функцій дистанційного навчання в електронному середовищі (організаційна, навчально-пізнавальна,

комунікаційна, діагностична) [2, с. 23].

Для досягнення практичної ефективності професійної підготовки майбутніх кваліфікованих робітників засобами дистанційного навчання необхідна наявність та правильне використання ресурсів організаційно-методичного блоку, що представлений у моделі організаційнопедагогічними умовами та методичним супроводом дистанційного професійного навчання.

У контексті опису моделі зазначимо, що організаційно-педагогічні умови дистанційного професійного навчання представлені трьома блоками, а саме: організаційно-технічнй (наявність нормативно-правового супроводу дистанційної освіти; наявність спеціалізованої системи дистанційного навчання), змістово-процесуальний (розробка та розміщення в електронному середовищі сучасних педагогічних програмних комплексів (дистанційних курсів); застосування змішаного навчання у професійній підготовці кваліфікованих робітників), особистісно-професійний (рівень володіння учнями (слухачами) ITтехнологіями; безперервний розвиток готовності педагогів до впровадження технологій дистанційного навчання).

Важливою умовою якісного застосування методик дистанційного навчання в освітньому процесі (методика організації самостійної роботи засобами дистанційного навчання; методика використання елементів дистанційного навчання у професійній підготовці, методика моніторингу та контроль успішності дистанційного професійного навчання) $\epsilon$ підготовка педагогів ЗППТО до здійснення таких педагогічних дій. Саме тому методика підготовки педагогічних працівників до застосування дистанційного навчання передбачає теоретичну підготовку (ознайомлення 3 особливостями дистанційного освітнього процесу) та практичну роботу щодо набуття досвіду створення дистанційних курсів на основі технології проектування дистанційних курсів, що органічно поєднує методику ADDIE, модульну методику МОП i принципи змішаного навчання (blended learning). 


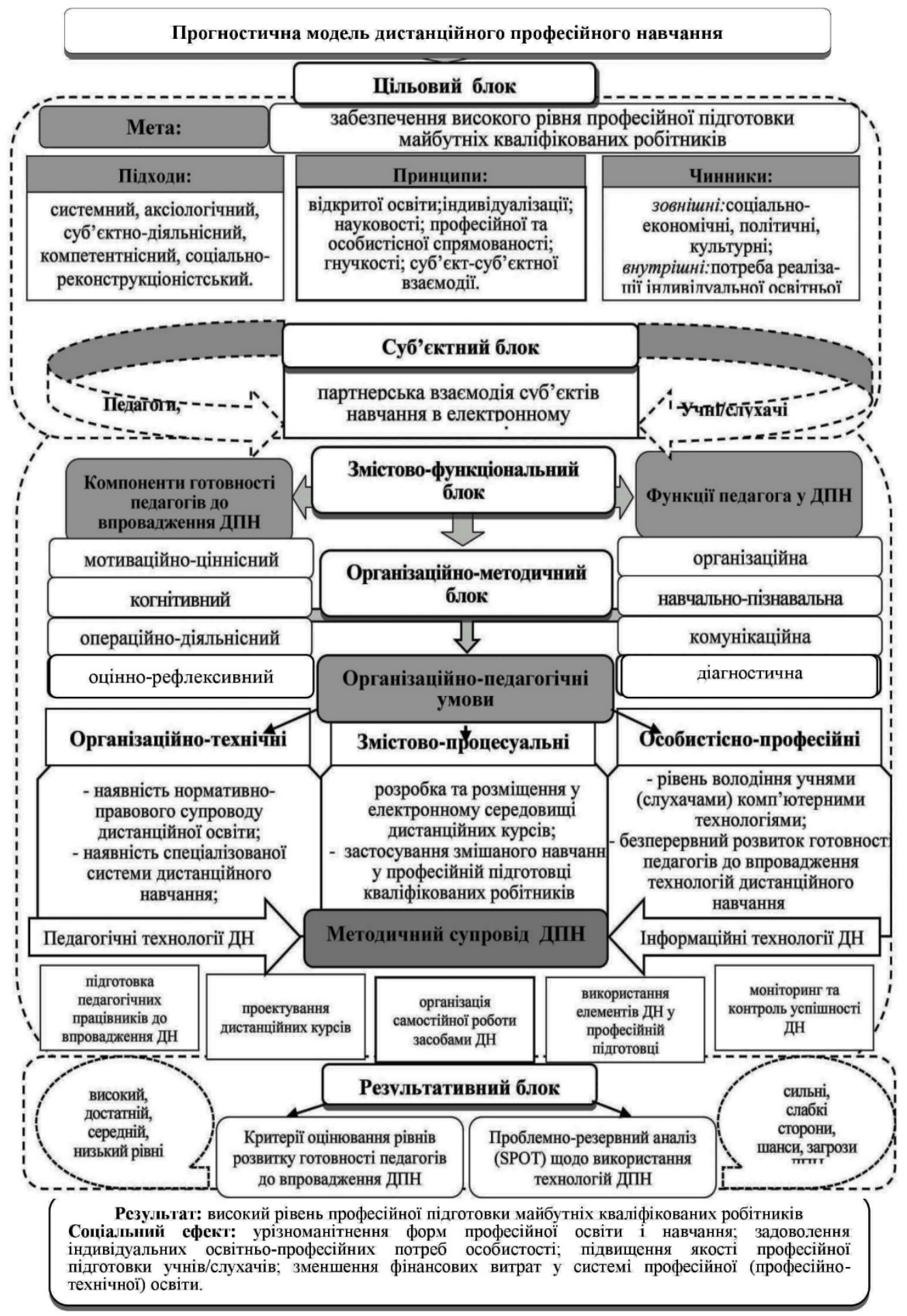

Рис. 1. Прогностична модель дистанційного професійного навчання

Результативний відображає механізми розвитку готовності блок моделі оцінювання рівнів педагогів до впровадження дистанційного професійного навчання за критеріями, що співвідносяться із визначеними компонентами, та ефективність 
застосування дистанційного навчання у ЗП(ПТ)О, яка визначається використанням SРОТ-проблемно-резервного аналізу.

\section{Виновок.}

прогностичної моделі дистанційного професійного навчання у ЗП(ПТ)О із чіткою орієнтацією на специфіку професійної підготовки майбутніх кваліфікованих робітників відносно обраної професії забезпечить досягнення соціального ефекту, а саме: урізноманітнення форм професійної освіти і навчання; задоволення індивідуальних освітньо-професійних потреб особистості; підвищення якості професійної підготовки учнів/слухачів; зменшення фінансових витрат у системі професійної (професійно-технічної) освіти тощо.

Перспективи подальших досліджень будуть присвячені аналізу результатів формувального етапу експерименту щодо перевірки ефективності прогностичної моделі дистанційного професійного навчання та організаційно-педагогічних умов його впровадження у процес професійної підготовки майбутніх кваліфікованих робітників у закладах освіти.

\section{Лiтература:}

1. Концепція розвитку дистанційної освіти в Україні. Постанова МОН України 20. 12. 2000 р. Режим http://www.osvita.org.ua/distance/pravo/00.html. доступу:

2. Кравець С. Г. Суть i компоненти готовності педагогів до впровадження дистанційного навчання кваліфікованих робітників / С. Г. Кравець // Науковий вісник Інституту професійно-технічної освіти НАПН України. Професійна педагогіка : зб. наук. праць: Вип. 12 / Ін-т проф.-тех. освіти НАПН України ; [Ред. кол. : В. О. Радкевич (голова) та ін.]. К. : Міленіум, 2016. - С. 88-97.

3. Кравець С. Г. Функції дистанційного навчання у системі професійної підготовки майбутніх кваліфікованих робітників / С.Г. Кравець // Матеріали науково-практичного семінару [«Використання платформи дистанційного навчання e-learning.org.ua в освітньому процесі професійнотехнічного навчального закладу»], (26 квіт. 2016 р.). - C. 21-24. - Режим доступу: http://ivetua.science/images/Journals_IPTO/Arhive/Seminar20160426-proceedings.pdf.

4. Підготовка педагогічних працівників професійно-технічних навчальних закладів до дистанційного навчання кваліфікованих робітників / [О.В.Базелюк, А. А. Каленський, С. Г. Кравець та ін.]. - Київ : ІПТО НАПН України, 2017. - 76 с.
5. Про затвердження Національної рамки кваліфікацій. Постанова Кабінету Міністрів України № 1341 від 23 листопада 2011 р. - [Електронний pecypc]. - Режим доступу : http://zakon4.rada.gov.ua/.

6. Про затвердження Положення про дистанційне навчання. Наказ Міністерства освіти і науки від 25.04.2013 № 466. - Режим доступу: http://zakon4.rada.gov.ua/laws/show/z0703-13.

7. Про освіту. - [Електронний ресурс] : Закон України від 05 вер. 2017 р. № 2145-VIII // Законодавство України / ВР України : [офіц. вебпортал]. - - Режим доступу : http://zakon2.rada.gov.ua/laws/show/2145-19/page/.

8. Сурмін Ю. П. Майстерня вченого: Підручник для науковця / Ю. П. Сурмін. - К. : Навчально-методичний центр «Консорціум 3 удосконалення менеджмент-освіти в Україні», 2006. $-302 \mathrm{c}$.

9. Ягупов В. В. Суб’єктність учнів як основна детермінанта дистанційного навчання в системі професійно-технічної освіти / В. В. Ягупов // Наук. вісник Ін-ту проф.-тех. освіти НАПН України. Професійна педагогіка : зб. наук. праць : Вип. 11 / Інст-т проф.-тех. освіти НАПН України ; [Ред. кол. В. О. Радкевич (голова) та ін.]. - К. : Міленіум, 2016. - C. 29-37.

\section{Реферат}

Прогностическая модель дистанционного профессионального обучения

Светлана Кравец, кандидат педагогических наук, стариий научный сотрудник лаборатории дистанциионного профессионального обучения Института профессионально-технического образования НАПН Украинь

\section{КЛЮЧЕВЫЕ СЛОВА: \\ дистанционное образование, дистанционное профессиональное обучение, прогностическая}

На основе анализа законодательных актов и нормативно-правовых документов установлено, что актуальность внедрения дистанционного образования усиливается социальными, политическими, культурными вызовами общества, что обусловливает потребность в обновлении нормативно-правового сопровождения дистанционного обучения, очерчивании новых возможностей по его внедрению и финансированию.

Охарактеризована деятельность ученых и практиков относительно постепенного внедрения дистанционного обучения в учреждениях профессионального (профессионально-технического) образования и обеспечения функционирования организационной структуры дистанционного профессионального образования, которая 
модель дистанционного профессионального обучения, учреждения профессионального (профессиональнотехнического) образования соотносится с явлениями, объектами, процессами, которые являются определяющими в системе профессиональной (профессионально-технического) образования.

Обосновано прогностическую модель дистанционного профессионального обучения, которая содержит следующие блоки: целевой - цель, концептуальные подходы и принципы, внешние и внутренние факторы; субъектный, что предполагает партнерское взаимодействие субъектов обучения (педагогов, тьюторов, администраторов СДО, учеников / слушателей) в электронной среде; содержательно-функциональный, содержащий компонентную структуру готовности педагогов к внедрению дистанционного обучения квалифицированных рабочих и функции, которые должен реализовывать педагог в дистанционном профессиональном обучении; организационно-методический представлен организационно-педагогическими условиями и методическим сопровождением их реализации; результативный блок - механизмы оценки динамики уровней развития готовности педагогов к внедрению дистанционного профессионального обучения и эффективность дистанционного обучения в учреждениях профессионального (профессионально-технического) образования.

Обобщено, что внедрение прогностической модели дистанционного профессионального обучения в учреждениях профессионального (профессиональнотехнического) образования с четкой ориентацией на специфику профессиональной подготовки будущих квалифицированных рабочих относительно выбранной профессии обеспечит достижение социального эффекта, а именно: разнообразие форм профессионального образования и обучения; удовлетворение индивидуальных образовательно-профессиональных потребностей личности; повышение качества профессиональной подготовки учащихся / слушателей; уменьшение финансовых затрат в системе профессиональной (профессионально-технического) образования.

\title{
Abstract
}

\section{Relevant prognostic model of distance professional learning}

\author{
Svitlana Kravets, \\ $P h D$ in Pedagogical Sciences, \\ Senior Research Fellow of the Laboratory of Distance Professional Learning \\ at the Institute for Vocational Education \\ of the National Academy of Pedagogical Sciences of Ukraine
}

\section{KEY WORDS:}

distance education, distance professional learning, relevant prognostic model of distance professional learning, professional (vocational) education institutions
Based on the analysis of legislative acts and regulatory documents, it was found that the relevance of introducing distance education is enhanced by social, political and cultural challenges of society, which necessitates updating legal support of distance learning, outlining new possibilities for its implementation and financing.

The activities of scholars and practitioners related to gradual introducing distance learning in professional (vocational) education institutions and ensuring organizational functioning of distance professional education that correlates with those phenomena, objects, processes, which are decisive in the system of professional (vocational) education, were described.

The relevant prognostic model of distance professional learning was justified. It contains the following blocks: target block includes the aim, conceptual approaches and principles, external and internal factors; subject block provides for partnership interaction between the subjects of education (teachers, tutors, distance learning managers, students/listeners) within the electronic environment; content and function block contains the component type structure of teachers' readiness to implement distance learning for qualified specialists, as well as the functions, which should be implemented by the teacher in distance professional learning; organization and methodology block involves organizational and pedagogical conditions and methodical support of their implementation; efficiency block encompassess the mechanisms for assessing dynamics in development levels of teachers' readiness to implement distance professional learning and effectiveness of using distance learning in professional (vocational) education institutions.

It was concluded that the process of introducing the relevant prognostic model of distance professional learning in professional (vocational) education institutions with clear orientation towards the specifics of training future qualified specialists within the chosen profession would promote the social effect, namely, diversified forms of vocational education and training; satisfied personal educational and professional needs of the individual; improved quality of vocational training; reduced financial expenses in the system of professional (vocational) education.

\section{References}

1. The Concept of Distance Education Development in Ukraine. The Decree of the Ministry of Education and Science of Ukraine as of December 20,
2000. - Mode of access : http://www.osvita.org.ua/distance/pravo/00.html.

2. Kravets S. H. The Essence and Components of Teachers' Readiness to Implement Distance Learning 
for Qualified Specialists / S. H. Kravets // Scientific Bulletin of the Institute for Vocational Education of the National Academy of Pedagogical Sciences of Ukraine. Professional Pedagogy: the Collection of Scientific Works: Issue 12 / the Institute for Vocational Education of the NAPS of Ukraine; [Editorial board : V. O. Radkevych (editor-in-chief) et al.]. - K. : Millennium, 2016. - P. 88-97.

3. Kravets S. H. Functions of Distance Learning in the System of Future Qualified Specialists' Professional Training / S. H. Kravets // Proceedings of the Scientific Practical Seminar [Using e-learning.org.ua Distance Learning Platform in the Education Process of Vocational Education Institution”] (April 26, 2016). P. 21-24. Mode of access : http://ivetua.science/images/Journals_IPTO/Arhive/Seminar-

20160426-proceedings.pdf.

4. Training Vocational Education Teachers to Provide Distance Learning for Qualified Specialists / [O. V. Bazeliuk, A. A. Kalenskyi, S. H. Kravets et al.]. - K. : IVE NAPS of Ukraine, 2017. - 76 p.

5. On Approval of the National Qualifications Framework. The Decree of the Cabinet of Ministers of Ukraine No 1341 as of November 23, 2011 [Electronic resource]. - Mode of access : http://zakon4.rada.gov.ua/.
6. On Approval of the Provision on Distance Learning. The Order of the Ministry of Education and Science as of 04/25/2013 No 466. - Mode of access : http://zakon4.rada.gov.ua/laws/show/z0703-13.

7. On Education [Electronic resource]: the Law of Ukraine as of September 5, 2017 No 2145-VIII // The Legislation of Ukraine / The Verkhovna Rada of Ukraine: [Official web-portal]. - Mode of access : http://zakon2.rada.gov.ua/laws/show/2145-19/page/.

8. Surmin Yu. P. The Scholar's Workshop: Textbook for Scholar. - K. : The Educational Center "Consortium for Improving Management Education in Ukraine”, 2006. - 302 p.

9. Yahupov V. V. The Subjectivity of Students as the Main Determinant of Distance Learning in the System of Vocational Education / V. V. Yahupov // Scientific Bulletin of the Institute for Vocational Education of the National Academy of Pedagogical Sciences of Ukraine. Professional Pedagogy: the Collection of Scientific Works: Issue 11 / the Institute for Vocational Education of the NAPS of Ukraine; [Editorial board : V. O. Radkevych (editor-in-chief) et al.]. - K. : Millennium, 2016. - P. 29-37.

УДК: 37.015 .31

\section{МОДЕЛЬ ВИЯВЛЕННЯ ТА РОЗВИТКУ ЗДІБНОСТЕЙ СТУДЕНТІВ}

\section{Валентин Чимшир,}

доктор технічних наук, доцент,

директор Дунайського інституту Національного університету

«Одеська морська академія».

ORCID: 0000-0003-3621-2702

Василь Желясков,

кандидат педагогічних наук, доцент,

завідувач кафедри гуманітарних дисииплін

Дунайського інституту Наиіонального університету

«Одеська морська академія»

\section{КЛЮЧОВІ СЛОВА:}

педагогічна система, здібності студента, розвиток обдарованості, виховання,

самовиховання, самоосвіта, освітній процес

\footnotetext{
Реферат

Стаття спрямована на розробку моделі виявлення та розвитку обдарованості студентів шляхом контролю, моніторингу та коригування освітніх процесів. У сучасному світі високій рівень інтелекту стає запорукою нових можливостей, досягнень, перспектив статусу в соціальному середовищі. Крім того, багатьма вченими, які вивчають педагогічні системи в різних умовах розвитку, визначається така класифікація обдарованості, яка фактично вказує, що кожний індивідуум обдарований, тільки потрібно визначити категорію та напрям, де він може це продемонструвати. Для досягнення мети дослідження визначаються п'ять умов розвитку обдарованості, які включають зовнішні і внутрішні якості студентів: загальні здібності; спеціальні здібності в конкретній області; спеціальні здібності неінтелектуального характеру; стимулююче оточення; випадкові фактори. Наводиться приклад виявлення обдарованості та етапи ії розвитку. В основі розробленої двоетапної моделі лежить ступенева система виявлення, моніторингу та корекції педагогічної системи, спрямованої на зростання творчого потенціалу, пізнавальної діяльності та мотивації студентів до самовдосконалення.

Модель першого етапу виявлення та розвитку обдарованості розкриває особливості роботи шкільної педагогічної системи. Традиційне визначення рівня інтелектуальної зрілості, первинної сформованості пізнавальних процесів, які забезпечують шкільну успішність, починається зі співбесіди, що дає змогу виявити сфери, в яких учень найбільш комфортно себе почуває. У подальшому застосування програмних засобів, методів спостереження та коригування освітніх процесів дає змогу на час вступу до вищого навчального закладу сформувати систему розуміння свого рівня обдарованості.

Модель другого етапу зосереджена на специфіці вищого навчального закладу та вимагає від студента емоційної зрілості, готовності до серйозного навантаження. У процесі навчання для кожного студента куратор або психолог заводить персональну картку, до якої упродовж усього навчання заносяться всі дані його інтелектуального розвитку, а потім разом 3 методичною радою вибудовується індивідуальний профіль його розвитку та обираються прийоми і способи подальшої роботи.
} 